\title{
Influence of included drill angle on cutting forces during drilling of aluminum alloy
}

\author{
Wpływ kąta wierzchołkowego wiertła na siły skrawania \\ podczas wiercenia stopu aluminium
}

\section{PAWEK PIEŚKO \\ MAGDALENA WOŹNIAK \\ MAGDALENA ZAWADA-MICHAŁOWSKA *}

The paper presents the analysis of the influence of the twist drill geometry, in particular the $2 \mathrm{Kr}$ angle, on the cutting forces during holes drilling in the element made of aluminum alloy for plastic forming EN AW-2024. In addition, the impact of the application of the drill geometry correction on the values of cutting forces was also investigated. During the tests, the values of components $F_{\mathrm{x}}, F_{\mathrm{y}}$ and $F_{\mathrm{z}}$ of the cutting force for tools with different geometry with the set, variable technological parameters, i.e.: feed $f$ and cutting speed $v_{c}$ were measured. The changes in the value of the axial component $F_{z}$ were analyzed in detail. It was found that the use of drills with an angle of $2 \mathrm{Kr}_{\mathrm{r}}<100^{\circ}$, due to the significant value of the axial force $F_{z}$ and high amplitude is unfavorable. Also, the lack of drill correction translates into an increase in the value of the axial force $F_{z}$ and its amplitude.

KEYWORDS: drilling, cutting forces, aluminum alloy, drill geometry

Hole machining is one of the most common technological treatments and therefore twist drills are popular cutting tools. The drilled holes have diameters ranging from hundredths of parts to even several hundred millimeters, with holes up to $100 \mathrm{~mm}[4,6,10]$ usually made using twist drills. It should be emphasized that drilling in comparison with other methods of processing takes place in relatively difficult conditions, because [11, 13]:

- load on the cutting edge is high;

- bits have relatively low stiffness for bending and twisting;

- cutting speed varies from the largest on the outside diameter to zero in the drill axis;

- chip evacuation, especially in long openings, is difficult;

- machining fluid has difficult access to the cutting zone. Value of the cutting force during drilling depends on many factors, including from [1, 2]:

- properties of the work material,

- technological parameters used,

- length of the transverse cutting edge (shear),

- size of the apex angle $2 \kappa_{\mathrm{r}}$,

- helix angle $\lambda^{\prime}$ s.

\footnotetext{
* Dr inż. Paweł Pieśko (p.piesko@pollub.pl), inż. Magdalena Woźniak, mgr inż. Magdalena Zawada-Michałowska (m.michalowska@pollub.pl) Katedra Podstaw Inżynierii Produkcji, Wydział Mechaniczny Politechniki Lubelskiej
}

In the literature, the apex angle $2 \kappa_{\mathrm{r}}$ impact on the value of the axial force is not clearly defined. According to some authors and the results of research [1,3], increasing this angle causes an increase in the value of axial force. The results of other works $[5,12]$ are opposite. It seems that the type of material being processed is of decisive importance $[1,11]$. Increasing the angle $\lambda_{\text {s }}^{\prime}$ causes an increase in the angle of attack, which translates into a reduction in cutting resistance and thus an axial force.

The value of the axial force is also influenced by the shape of the flank [14] and the geometry of the transverse cutting edge [1, 11], which is characterized by negative values of the rake angle with very large absolute values (up to $-60^{\circ}$ ), which translates into the formation of a very high axial force. Therefore, the drill geometry correction is often applied, which involves shortening or removing the cut (tab. I) $[7,8,11]$

TABLE I. Types of sharpening drill bits (in accordance with DIN 1412) [7]

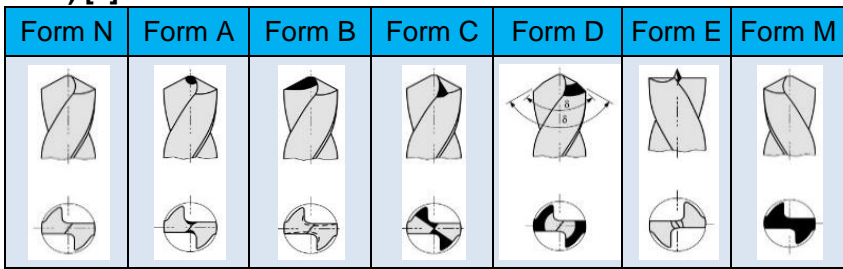

$\mathrm{N}$ - Grounded conical surface

A - Grounded conical surface with shortening of the perpendicular blade - type A

B - Grounded conical surface with shortened perpendicular blade with shear correction - type B

C - Grounded conical surface with shortening of the perpendicular blade - type C

D - Grounded conical surface, a broken blade - type D

E - Sharpening with a $180^{\circ}$ front angle and an axial blade

- type E

M-Micro-drills

\section{Methodology}

The impact of the value of the double angle of incidence $2 \kappa_{\mathrm{r}}$ (angle of the apex) and the absence or use of correction C (according to DIN 1412) on the value of the axial component $F_{\mathrm{z}}$ of the cutting force was evaluated. As part of the research, drilling tests were carried out with NWKa twist drills (DIN $338 \mathrm{RN}$ ) with a diameter of $9 \mathrm{~mm}$ (fig. 1). 


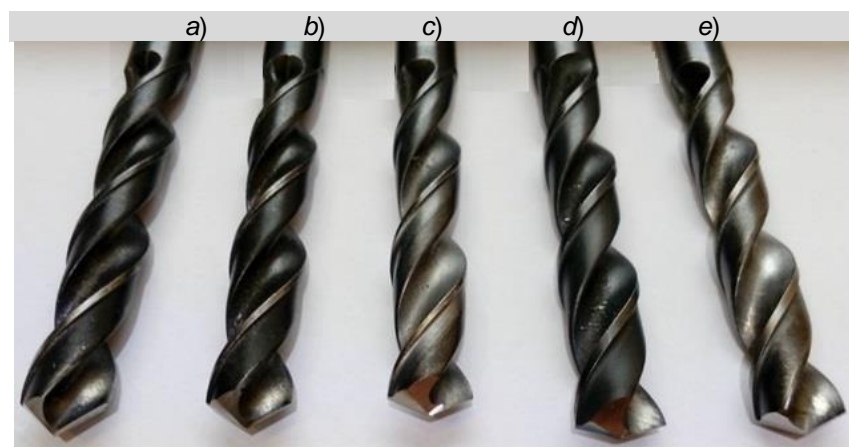

Fig. 1. Drills used in tests: a) $2 \kappa_{\mathrm{r}}=90^{\circ}$, correction C; b) $2 \kappa_{\mathrm{r}}=100^{\circ}$ correction C; c) $2 \kappa_{\mathrm{r}}=118^{\circ}$, correction C; d) $2 \kappa_{\mathrm{r}}=135^{\circ}$, correction C; e) $2 \kappa_{\mathrm{r}}=118^{\circ}$, without correction

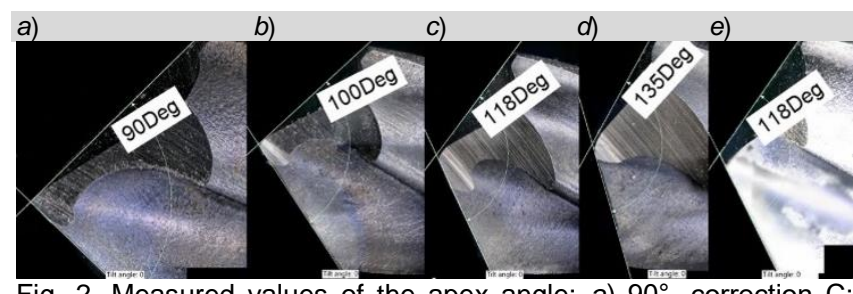

Fig. 2. Measured values of the apex angle: a) $90^{\circ}$, correction $\mathrm{C}$ b) $100^{\circ}$, correction C; c) $118^{\circ}$, correction C; d) $135^{\circ}$, correction C; e) $118^{\circ}$, without correction

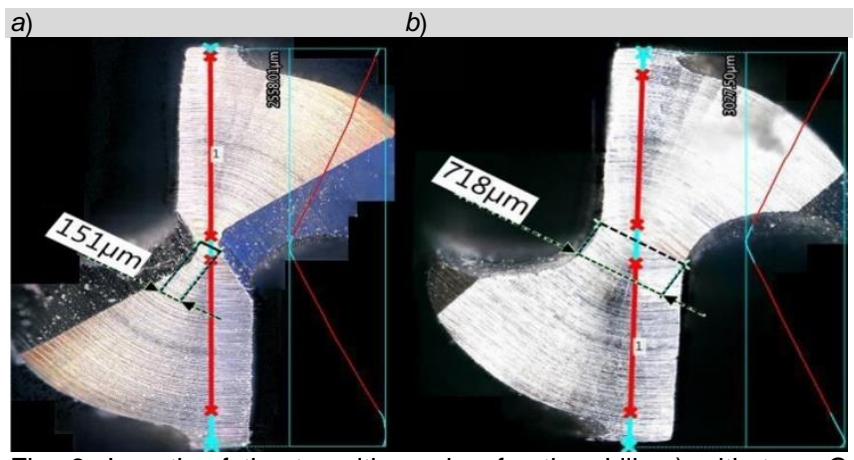

Fig. 3. Length of the transition edge for the drill: a) with type $C$ correction; $b$ ) without correction

TABLE II. Technological parameters used

\begin{tabular}{|c|c|c|}
\hline $\begin{array}{c}\text { Sample } \\
\text { number }\end{array}$ & Cutting speed $v_{\mathrm{c}}, \mathrm{m} / \mathrm{min}$ & Feedrate $f, \mathrm{~mm} / \mathrm{rev}$ \\
\hline 1 & 60 & 0,12 \\
\hline 2 & 60 & 0,14 \\
\hline 3 & 60 & 0,16 \\
\hline 4 & 60 & 0,18 \\
\hline 5 & 60 & 0,20 \\
\hline 6 & 40 & 0,16 \\
\hline 7 & 50 & 0,16 \\
\hline 8 & 70 & 0,16 \\
\hline 9 & 80 & 0,16 \\
\hline
\end{tabular}

Angle values of $2 \kappa_{r}$ were changed in the range of $90 \div 135^{\circ}$. To obtain the required geometry, the drill was ground on a Cormak sharpener and then measured. The measured values of the apex angle are shown in fig. 2 . For drills with a standard angle of $2 K_{\mathrm{ma}}=118^{\circ}$, the length of the transition edge (shear) was also measured, with correction (fig. 3a) and without correction (fig. 3b). The use of correction allowed more than fourfold reduction in shear length, which translated into lower cutting force.

During the drilling tests, variable machining parameters were used - their values are listed in tab. II.

The holes were drilled in a plate with a thickness of $10 \mathrm{~mm}$, made of aluminum alloy for plastic forming EN AW2024 T351 - the chemical composition and selected mechanical properties of this material are given in the tab. III.

The tests were carried out on a vertical milling center FV$580 \mathrm{~A}$. The Kistler set consisting of:
- piezoelectric dynamometer 9257B

- four-channel 5070 load amplifier,

- DAQ module with built-in A/D card,

- DynoWare software, allowing data acquisition and analysis.

The cutting force measurements were repeated four times. In addition, the wear status of the cutting blades was monitored.

TABLE III. Chemical composition and selected mechanical properties of EN AW-2024 alloy [9]

\begin{tabular}{|c|c|c|c|c|c|c|c|c|}
\hline \multicolumn{8}{|c|}{ Concentration of elements, \% } \\
\hline $\mathrm{Si}$ & $\mathrm{Fe}$ & $\mathrm{Cu}$ & $\mathrm{Mn}$ & $\mathrm{Mg}$ & $\mathrm{Cr}$ & $\mathrm{Zn}$ & $\mathrm{Ti}$ & Others \\
\hline $0 \div 0.5$ & $0 \div 0.5$ & $3.8 \div 4.9$ & $0.3 \div 0.9$ & $1.2 \div 1.8$ & $0 \div 0.1$ & $0 \div 0.25$ & $0 \div 0.15$ & $0 \div 0.15$ \\
\hline \multicolumn{7}{|c|}{ Selected mechanical properties } \\
\hline $\begin{array}{c}\text { Density } \rho, \\
\mathrm{g} / \mathrm{cm}^{3}\end{array}$ & $\begin{array}{c}\text { Young's } \\
\text { modulus } E, \\
\mathrm{GPa}\end{array}$ & $\begin{array}{c}\text { Tensile } \\
\text { strength } R_{\mathrm{m}}, \\
\mathrm{MPa}\end{array}$ & $\begin{array}{c}\text { Conventional } \\
\text { yield point } R_{\mathrm{p} 0,2}, \\
\mathrm{MPa}\end{array}$ & $\begin{array}{c}\text { Brinell } \\
\text { hardness } \\
\mathrm{HB}\end{array}$ \\
\hline 2.78 & 73 & 430 & 290 & 122 \\
\hline
\end{tabular}

\section{Results}

The measurements made allowed to determine the time courses of components $F_{\mathrm{x}}, F_{\mathrm{y}}, F_{\mathrm{z}}$ cutting forces. An example of such a waveform for $v_{\mathrm{c}}=60 \mathrm{~m} / \mathrm{min}$ and $f=0.16 \mathrm{~mm} / \mathrm{rev}$ is shown in fig. 4. After analyzing the measurement results it was found that the values of $F_{\mathrm{x}}$ and $F_{\mathrm{y}}$ constituted approx. $3 \div 10 \%$ of the axial component $F_{z}$, therefore at subsequent stages of research, the focus was on the assessment of this strength. In some cases, a slight increase in the values of the $F_{x}$ and $F_{y}$ components was observed in the final phase of the borehole, i.e. when the drill bit exited from the material.

Fig. 5 shows the time courses of the $F_{z}$ component at $v_{c}$ $=60 \mathrm{~m} / \mathrm{min}$ and $f=0.16 \mathrm{~mm} / \mathrm{rev}$ for four drills with an angle of $2 \mathrm{Kr}$ from $90^{\circ}$ to $135^{\circ}$.

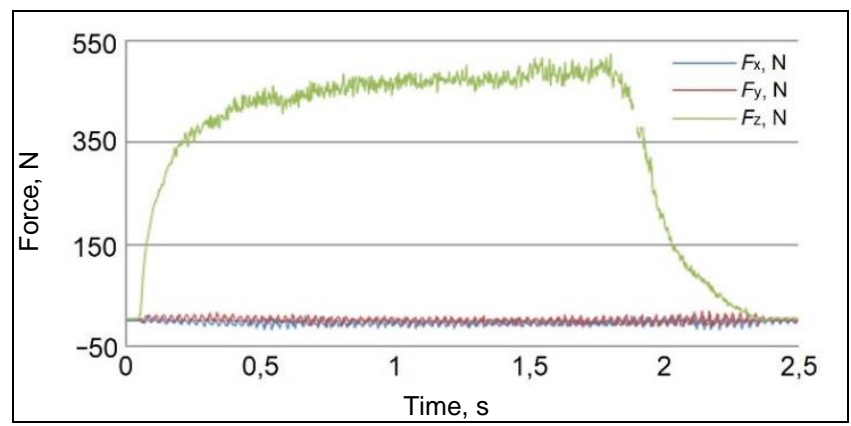

Fig. 4. Components $F_{\mathrm{x}}, F_{\mathrm{y}}, F_{\mathrm{z}}$ cutting forces. Machining parameters: $v_{\mathrm{c}}=60 \mathrm{~m} / \mathrm{min}, f=0.16 \mathrm{~mm} / \mathrm{rev}$

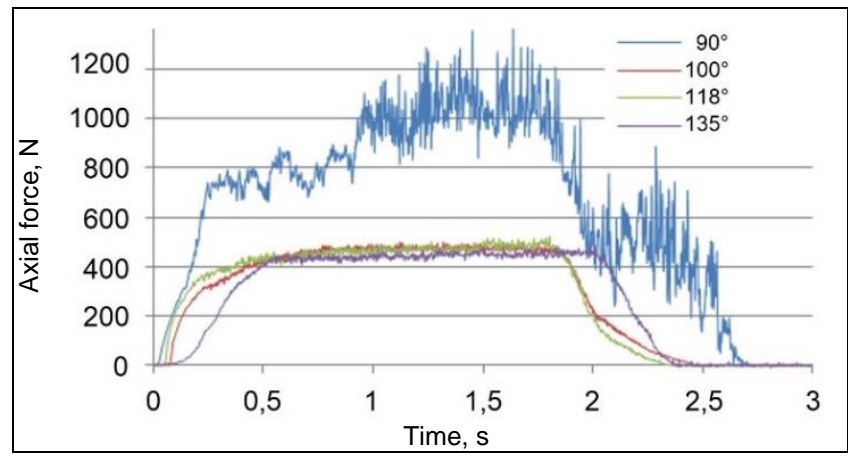

Fig. 5. Time progresses of the axial component $F_{z}$ for drills with different angles of $2 a_{\mathrm{m}}$. Machining parameters: $v_{\mathrm{c}}=60 \mathrm{~m} / \mathrm{min}, f=$ $0.16 \mathrm{~mm} / \mathrm{rev}$

For drills with $2 \mathrm{Kr}_{\mathrm{r}}$ angles in the range from $100^{\circ}$ to $135^{\circ}$, the measured values of axial force have similar values and range from 420 to $480 \mathrm{~N}$. For a drill with an angle of 
$2 k_{\mathrm{r}}=90^{\circ}$, value of the $F_{\mathrm{z}}$ component is more than twice as large, and also the time course for this drill, unlike the others, is very unstable. Changes in the $F_{z}$ component value have a significant amplitude, which is reflected in the standard deviations visible in fig. 6 .

In the examined range of cutting speeds for a drill with an angle of $2 K_{r}=90^{\circ}$, the value of the $F_{z}$ component increases with increasing speed. For other drills, the value of the axial component at the change of the cutting speed is kept at a similar level, with the lowest values obtained for the drill with an angle of $2 \kappa_{\mathrm{r}}=135^{\circ}$. It should be emphasized, however, that for this drill the $F_{z}$ component values are smaller - less than $10 \%$ in comparison with drills with an angle of $2 K_{\mathrm{r}}=$ $100^{\circ}$ and $2 \kappa_{\mathrm{r}}=118^{\circ}$. At the same time, the highest values of axial force were obtained from these three drills for a drill with a standard (commercial) angle of $2 \kappa_{\mathrm{r}}=118^{\circ}$. For the drill with this angle, the effect of the correction of its geometry on the value of the $F_{z}$ component was investigated. Time progresses of this component at $v_{c}=60$ $\mathrm{m} / \mathrm{min}$ and $f=0.16 \mathrm{~mm} / \mathrm{rev}$ for a drill with correction and without correction are shown in fig. 7 .

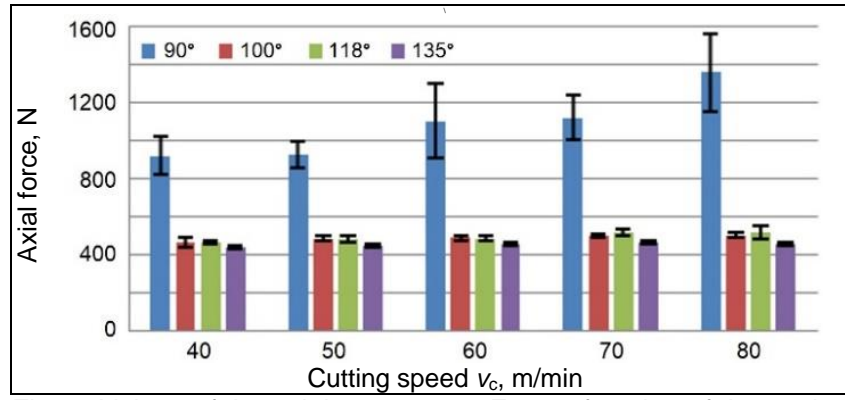

Fig. 6. Values of the axial component $F_{z}$ as a function of the cutting speed $v_{\mathrm{c}}$ for drills with different angles of $2 K_{\mathrm{r}}$

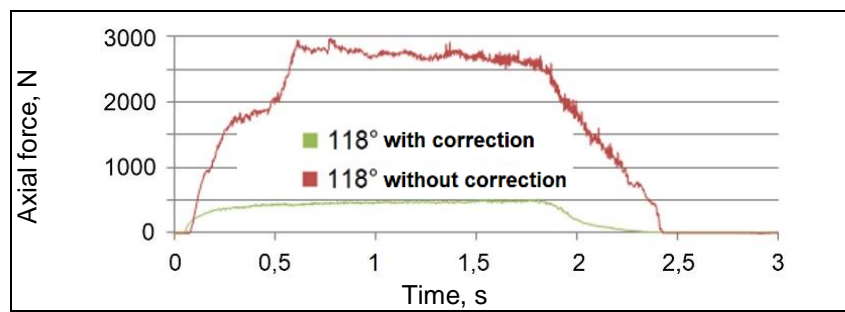

Fig. 7. Time progresses of the axial component $F_{z}$ for drills with and without correction. Machining parameters: $v_{\mathrm{c}}=60 \mathrm{~m} / \mathrm{min}, f=0.16$ $\mathrm{mm} / \mathrm{rev}$

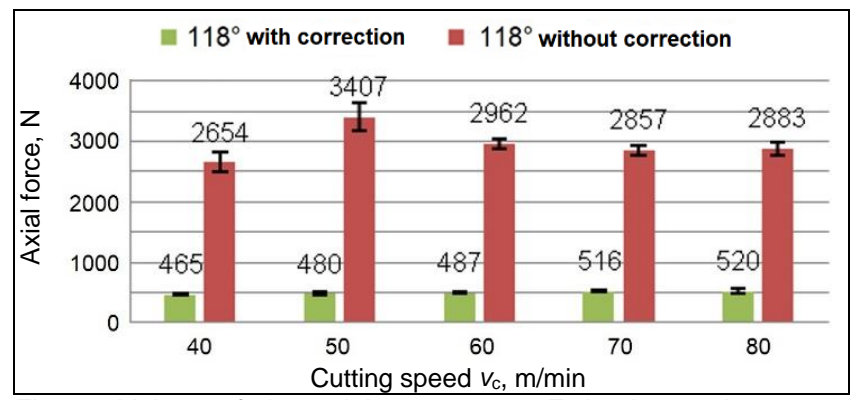

Fig. 8. Values of the axial component $F_{z}$ in the cutting speed function $v_{\mathrm{c}}$ for drills with and without

According to the data presented in fig. 8, the $F_{z}$ component values are over six times larger for a noncorrected drill (in comparison with a drill with correction). The largest differences (about seven times) of the axial force values for drills with and without correction were obtained for the cutting speed $v_{\mathrm{c}}=50 \mathrm{~m} / \mathrm{min}$. In the case of a drill without correction for this speed, the measured value of the force reached its highest value.

By analyzing the values of standard deviation and the time courses of forces, it can be concluded that machining with a non-correction drill is less stable.

\section{Conclusions}

The research allowed to formulate the following conclusions:

- The use of $2 k_{\mathrm{r}}<100^{\circ}$ burs for machining aluminum alloys is disadvantageous due to the significant value of the axial force and its high amplitude.

- According to the information contained in the literature, the lowest values of axial force were obtained for the highest apical angle $2 \kappa_{\mathrm{r}}=135^{\circ}$ used.

- Value of the axial force at the angle of $2 \kappa_{\mathrm{r}}=135^{\circ}$ is only slightly higher (by approx. 10\%) compared to the drills with angles of $2 K_{\mathrm{r}}=100^{\circ}$ and $2 K_{\mathrm{r}}=118^{\circ}$. It should therefore be assumed that in the case of AW-2024 drilling, the angle of $2 \kappa_{\mathrm{r}}$ may be in the range from $100^{\circ}$ to $135^{\circ}$ and does not significantly affect the value of the axial force.

- For an angle of $2 \mathrm{Kr}_{\mathrm{r}}=90^{\circ}$, the value of the axial force is more than twice as high as for the other drills and has the most unstable waveform.

- The lack of drill correction also translates into an increase in the value and amplitude of the axial force, which is disadvantageous for the drilling process.

- Value of the axial force for a drill without correction is more than six times greater than for a drill with a correction.

\section{REFERENCES}

1. Brodowicz W. „Skrawanie i narzẹdzia. Podręcznik dla technikum". "Warszawa: Wydawnictwa Szkolne i Pedagogiczne, 1993.

2. Dul-Korzyńska B. "Obróbka skrawaniem i narzędzia”. Rzeszów: Oficyna Wydawnicza Politechniki Rzeszowskiej, 2009.

3. Feito N., Díaz-Álvarez J., Díaz-Álvarez A., Cantero J.L., Miguélez M. H. "Experimental analysis of the influence of dril point angle and wear on the drilling of woven CFRPs". Materials. 7, 6 (2014): pp. 4258-4271.

4. Górski E. „Wiercenie, rozwiercanie i pogłębianie otworów”. Poradnik Inżyniera. Obróbka skrawaniem. T.1. Warszawa: Wydawnictwo Naukowo-Techniczne, 1991.

5. Jadhav S.S., Kakde A.S., Patil N.G., Sankpal J.B. "Effect of cutting parameters, point angle and reinforcement percentage on surface finish, in drilling of AL6061/AI2O3p MMC". Procedia Manufacturing. 20 (2018): pp. 2-11.

6. Kudła L. „Wpływ niewspółosiowości wiertła i wrzeciona na proces wiercenia mikrootworów". Mechanik. 7 (1998): pp. $447-450$.

7. Information materials of the RONAR company.

8. Information materials of the Wiertla BAILDON company.

9. PN-EN 573-3:2010 Aluminium i stopy aluminium - Skład chemiczny i rodzaje wyrobów przerobionych plastycznie Część 3: Skład chemiczny.

10. Oczoś K.E. „Obróbka otworów - osiągnięcia w zakresie wiercenia i drążenia. Cz. 1: Technika wiercenia mechanicznego". Mechanik. 5-6 (1997): pp. 175-187.

11. Olszak W. „Obróbka skrawaniem”. Warszawa: Wydawnictwo Naukowo-Techniczne, 2008

12. Satoshi E. "Effects of Twist Drill Point Geometry on Torque and Thrust". Sci. Rep. Fac. Educ. Gifu Unive. (Nat. Sci.). 36 (2012): pp. 165-174.

13. Zaleski K., Matuszak J. „Podstawy obróbki ubytkowej”. Lublin Wydawnictwo Politechniki Lubelskiej, 2016.

14. Zhu Z. „Evaluation of novel tool geometries in dry drilling aluminium 2024-T351/titanium Ti6Al4V stack". Journal of Materials Processing Technology. 259 (2018): pp. 270-281. .

Translation of scientific articles, their computer composition and publishing them on the website www.mechanik.media.p by original articles in Polish is a task financed from the funds of the Ministry of Science and Higher Education designated for dissemination of science.

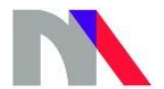

Ministry of Science and Higher Education

Republic of Poland 